\title{
U.S. Competitiveness And Global Markets
}

\author{
Anthony Narsing, Macon State College, USA \\ Arav Ouandlous, Savannah State University, USA \\ Harry G. McAlum, Macon State College, USA
}

\begin{abstract}
Since the beginning of the $19^{\text {th }}$ century, the U.S. economy achieved leadership and supremacy in technology, innovation and productivity. This uncontested supremacy was the result of the combined efforts of both private sector investment policies in research and development and the supporting funding government policies of these corporations. These combined efforts in capital intensive R\&D programs propelled the U.S. economy to the forefront of innovation and resulted in significant productivity gains--the drivers behind the U.S. long term economic growth, and the increases in the standards of living. Is the U.S. able to maintain its supremacy in innovationtechnology and thereby its economic leadership? The authors discuss this question in light of the recent role assumed by the newly emerging countries and their respective educational, technological and economic quest for global reach.
\end{abstract}

Keywords: global markets, competition, outsourcing, technology, investment, funding.

\section{INTRODUCTION}

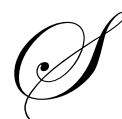

ince the beginning of the $19^{\text {th }}$ century, the U.S. economy achieved leadership and supremacy in technology, innovation and productivity. This uncontested supremacy was the result of the combined efforts of both private sector investment policies in research and development and the supportive funding government policies. These combined efforts in capital intensive R\&D programs have propelled the U.S. economy to the forefront of innovation and have resulted in significant productivity gains, which were the drivers behind the U.S. long term economic growth, and the increases in the standards of living. Is the U.S. able to maintain its supremacy in innovation-technology and thereby its economic leadership?

U.S. industries, equipped with a highly skilled workforce, established themselves as leaders in the field of high technology, nuclear energy, electronics, automotives, aviation and pharmaceuticals to cite a few. U.S. companies drew the ire of many nations with their ability to sustain competitiveness and world dominance in manufacturing industries and in management sciences. The leaders in management sciences and the noted efforts of gurus such as Shewart, Deming, Juran, and Crosby played vital roles in re-shaping the factory floor operations. They helped define strategic management initiatives and introduced management science to better understand and improve processes, which all served to enhance both quality and increased productive outputs [Stephenson, 2007].

Recently, however, the U.S. economy has been facing some serious challenges from both highly advanced industrialized nations such as Japan and Western European countries as well as emerging economies particularly those of India and China. It is becoming clear that China and India will continue to foster, promote and encourage internal and external growth in their respective economies by instituting political and economic policies geared toward global competitiveness. The awakening of these sleeping giants can pose a formidable challenge to the U.S. and other advanced industrialized nations. These new challengers are all positioning themselves to becoming key players in the new global markets. These markets are driven by technology, increased outsourcing and higher levels of skilled workforces. The key to this swift global race belongs to those who will have supremacy in innovation technology. Furthermore, those who will have the supremacy in innovation-technology will also have a claim on economic supremacy in global markets. Does the U.S. still have the wherewithal to continue leading the innovationtechnology global race despite facing stiff competition from highly developed and newly emerging countries? If it does, what would it take to retain this leadership? The authors discuss this question in light of the new role assumed 
by the newly emerging countries and their respective educational, technological and economic quest for global reach.

\section{ROLE OF EMERGING COUNTRIES}

Emerging countries such as China and India have established themselves as eminent players in global markets. In fact, China is poised to overtake Japan as the second most powerful economy in the world, second only to the U.S. The Chinese discovered that economic success cannot be achieved by their traditional communistic doctrine but rather by pursuing a hybrid approach--a combination of communism and capitalism. The evidence suggests such hybrid approach must have succeeded as China averaged a staggering 9.5\% annual growth during the past two decades [Engardio, 2005]. It is estimated that at this rate of growth, China's economy could be at least $75 \%$ greater than that of the U.S by 2050[Fishman, 2005]. This should be of no surprise as China is currently the world's leading producer of clothing and toys. They account for at least $40 \%$ of the total furniture sold in the U.S. market [Fishman, 2005]. By 2000, China staked its claim as the largest producer of consumer electronics. Next, it is poised to become a leader in biotechnology and computer manufacturing [Daggett and Pedinotti, 2005].

Let's not forget that China would not have this level of economic growth and success in global markets if it did not have access to such a large source of cheap labor. A combination of cheap labor and a highly skilled labor workforce, which includes engineers and scientists, allows China to gain strength in other areas such as mass manufacturing. Knowing that Chinese industries also needed a staple of non-skilled workers, the government relaxed its migration policies and allowed both peasants and farmers to move into urban centers to seek employment opportunities. The result is that China experienced a growth spurt with 100-160 cities having a population of at least one million people each, which sharply contrasts the U.S. that has nine and Europe with 36 [Fishman, 2005]. Growth in its cities was necessary to provide the labor to maintain current and future output.

Like China, India also benefits from a supply of highly skilled and non-skilled workers. In fact, India has established itself as the next Silicon Valley. It is recognized as a leader in information technology design and remains at the forefront in the development of both software and hardware. Of course, India could not achieve such measurable level of success, if it were not for economic liberalization and reforms set forth in 1991. These policy changes allowed India to attract varying levels of foreign investments and trade, which were both needed to boost its economic growth to $7 \%$. Prior to liberalization and reforms, growth was stagnant and remained under 3\%. Today, India's economy boasts at least $\$ 118$ billion in foreign currency [Freedman, 2005].

India's economic rise should not be alarming. Its economic success is partly explained by its vast innovation efforts and revolutionary developments in information technology. With its highly skilled workforce of software/hardware developers, India was able to attract companies like Motorola, Cisco Systems, Intel, HewlettPackard and Microsoft [Engardio, 2005]. Intel, Microsoft and Cisco all plan to invest at least 1 Billion dollars in India over the next three to five years [Mahapatra, 2005].

In recent years, India has experienced a plethora of IT outsourcing in the way of call centers, and U.S. federal tax return processing. Call centers account for approximately 245,000 jobs, while federal tax processing increased from an estimated 25,000 tax returns in 2003 to more than 400,000 in 2005. Even medical practitioners are getting involved in outsourcing. CT scans and digitized $\mathrm{x}$ rays are sent from U.S. doctors via electronic transmission to Indian doctors who provide their expert interpretation [Freedman, 2005]. An estimated 2000 scans were read by Indian doctors [PRNewswire, 2006]. Like China, many would agree that India's low wage high skilled labor workforce presents a definite competitive [advantage] in global markets.

\section{ECONOMIC POLICIES}

For several years during the 1970s and into the early 1980s, both Japan and the U.S. respectively, experienced "bubble" economies. The Japanese economic growth was attributed to advancement in technology innovation, which produced consumer popular electronics and automotive for exports. Its manufacturing industry during this period flourished. As a result of its economic growth, which peaked by the end of 1989, the Japanese 
invested heavily in American real estate and industrial markets [Thornton, 2007]. Unfortunately, its bubble started to collapse shortly thereafter. Over the next 18 months since its economic peak, the Japanese witnessed a sharp decline in the Nikkei stock market, which lost an estimated 75\% of its peak value. During the period from 1990 to 2004, the Japanese economy suffered from stagnation. In desperation for economic recovery, the Japanese government lowered interest rates, increased public works through deficit spending, reduced tariffs, and provided tax abatement to businesses in an effort to boost its economy. In the end, none of these measures seemed to provide a significant boost to the Japanese Economy.

In contrast, the American economy also experienced significant growth from the early 1980s until the early 2000s. Shortly after this period, its bubble began to burst. Both the Dow Jones industrial average and the NASDAQ Index experienced a significant decline in peak value, $40 \%$ and $75 \%$ respectively [Thornton, 2007]. The U.S. did not seem to learn much from the collapse of the Japanese economy, as it also embraced a slow recovery and instituted similar policies such as lowering interest rates, tax incentives and tariff relief. As the American economy continues to flounder, the Japanese economy appears to be on a path of recovery. Its automotive manufacturing industry is making significant grounds on the U.S. market. Using new products and superior operation strategies, Toyota has overtaken Ford in car sales, light and industrial trucks, second only to General Motors Corporation. Ford held its second place position in sales for 75 years [Durbin, 2008].

An explanation for the Japanese turnaround is linked to its economic policies, which for example favored import substitution and export promotion to protect its markets. Furthermore, the Japanese recognized that to compete in global markets, it must shift its focus from mature markets to those that are receptive to new technology enhancements. Successful transformation of its economy favors a free market approach in its centrally planned economy, which allows Japan to strengthen relations with its corporations by building trust, promoting shared results, and investing in profitable ventures [Thornton, 2007]. In contrast, U.S. policy makers are slow in responding to foreign threats and protecting its markets. There is a considerable trade imbalance between China and the U.S. which is affecting local industries and the survival of American jobs. Efforts by U.S. lobbyists, self-interest groups and foreign investors must be carefully monitored and regulated to protect U.S. interests.

\section{EDUCATION IMBALANCE}

The resounding theme emanating from emerging and developed countries is the need for increased skilled workers. China, India, Japan, Germany and other nations place a high degree of investment in educating its people, who are expected to be the driving force to successfully competing in global markets. Figure 1 below shows a declining trend in American College graduates as compared to those of China and India.

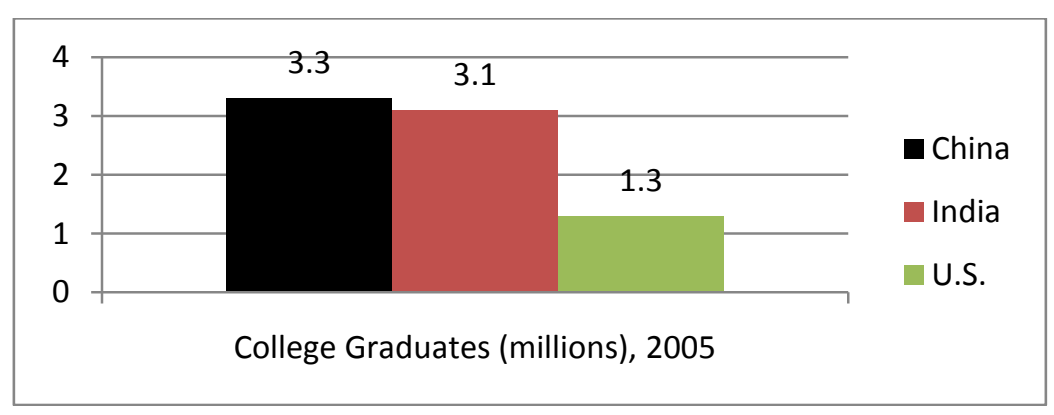

Figure 1. College Graduate in China, India and the U.S. [Source: Colvin, 2005]

More importantly, engineering remains a highly focused field of study by both China and India as shown in Figure 2. The rate at which these emerging countries are producing engineering graduates is a testament to their quest for attaining supremacy in global markets in areas such high technology and manufacturing. 


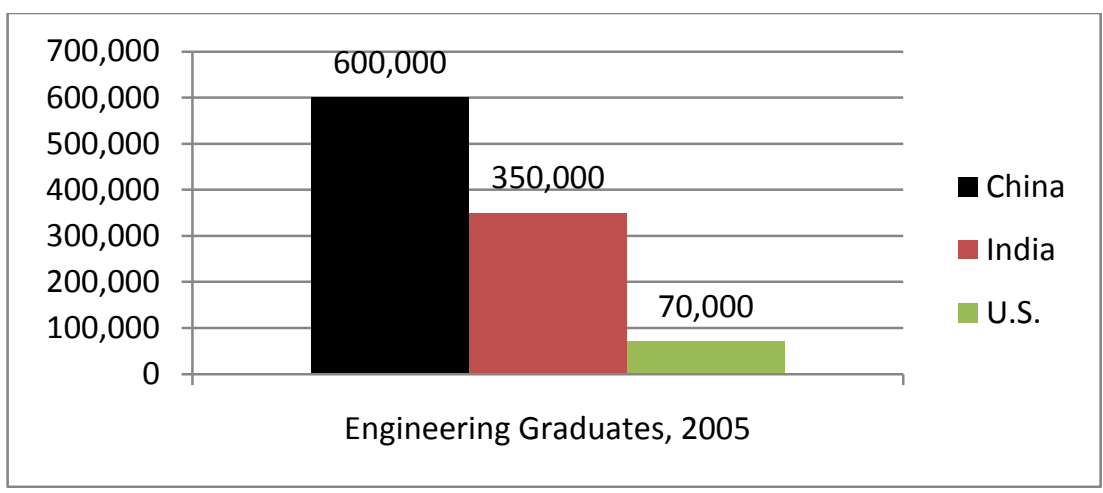

Figure 2. Engineering Graduates in China, India and the U.S. [Source: Colvin, 2005]

Comparatively, U.S. engineering graduates decreased by $20 \%$ from 1985 to 2004 . During this period China, Japan and South Korea engineering graduates have all increased. This is shown below in Figure 3. Further cuts by Congress to the 2005 National Science Foundation (NSF) budget amounted to \$105 million dollars. This move discouraged development in programs aimed at achieving skilled technical workforce. NSF was founded by Congress in 1950 to "promote the progress of science; to advance the national health, prosperity, and welfare..." Their goal was to help support innovation through sponsored R\&D programs by private and public institutions.

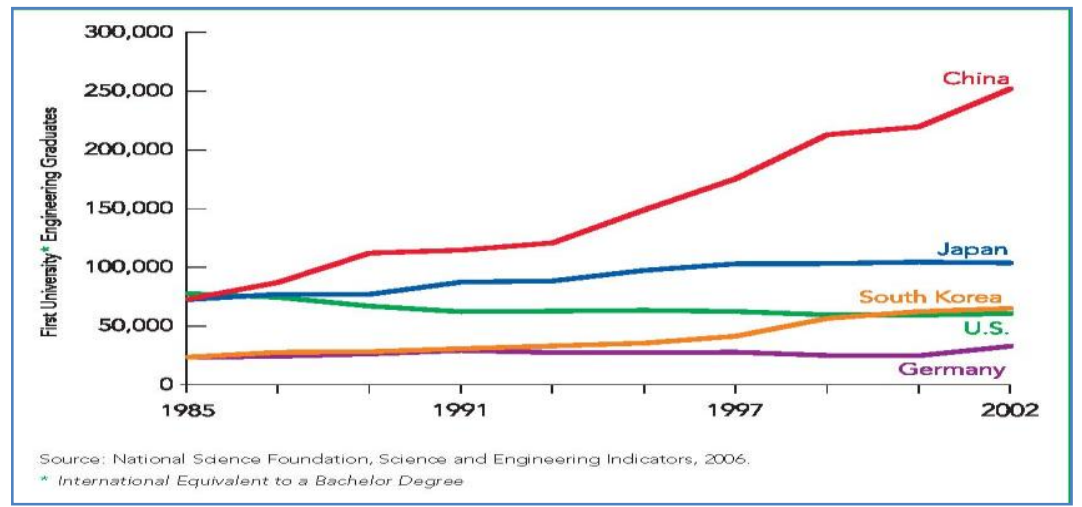

Figure 3. Engineering Graduates from 1985-2002. [Source: NSFEI, 2006]

Several reasons can be attributed to this decline in U.S. engineering graduates. For one, federal sponsored funding in R\&D geared towards physical sciences and engineering has been declining steadily from 1970 to 2000 as shown in Figure 4. In 1970, the federal government spent $0.25 \%$ of its GDP in physical sciences and engineering, as compared to $0.125 \%$ in 2003 . Such decline in spending will adversely impact U.S. companies in their ability to remain at the forefront of technology and innovation. 


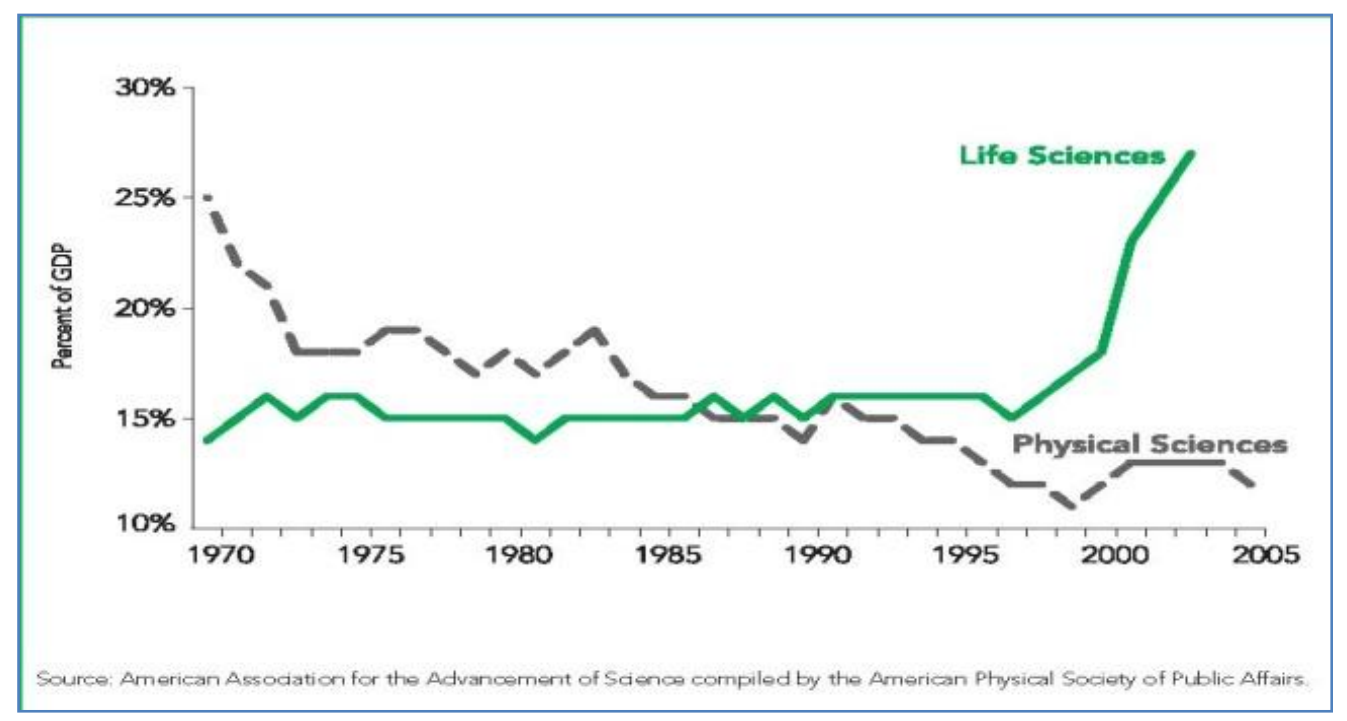

Figure 4. Federal Funding for Physical Sciences Spending [Source: AAAS, 2005]

\section{LESSONS LEARNED}

The above analysis has shown that U.S. and Japan have achieved their respective economic prowesses through heavy investments in their educational systems which produced highly skilled workforces that are responsible for today's advances in sciences and technologies and the spectacular growth in their respective economies. The governments of both countries committed a significant share of their respective GDP to support their respective educational systems and to fund their R\&D programs. The corporate sector in both countries has also fully participated and supported these efforts. It is the combined efforts of both the government and the private sector which explain to a certain extent the economic supremacy achieved by these two countries. As shown above, the U.S. government has recently reduced its share of R\&D funding and failed to reform effectively its educational system to bring it along with the exigencies of the modern high technology society. On the other hand, India and China are learning from the successes of U.S. and Japan past educational and funding policies and they are duplicating these policies to achieve their global quest.

To maintain its leadership role the U.S. government must take a more proactive stance -as it did in the pastat establishing policies aimed at creating opportunities for technology supremacy. The government must work closely with corporations through sponsored R\&D programs by monitoring and directing funding. In return, corporations must act responsibly in using funded research and share results so that other researchers can gain benefits. This will remove replication of research efforts in the system. Corporations must also make special efforts to reinvest in developing their workforces by sponsoring training programs to ensure continued professional development. Private and public institutions must play a vital role in also developing and promoting programs in technology fields.

The U.S. education system has for years been criticized for having less rigid standards in a child's early developmental years. In fact, it is documented that children have poor mathematical and computational skills. Studies go further to describe weaknesses in physical sciences. When compared to their counterparts abroad, twelth graders in the U.S. rate near the bottom of mathematical and sciences knowledge. A possible explanation is that little career guidance is provided early enough in their education to guide them in making or at least thinking about possible careers. While children can dream about being doctors, astronauts or even school teachers, they must be exposed early to the importance or math, physical sciences, social sciences and the like as well as the career opportunities in these fields. 


\section{CONCLUSION}

U.S. corporations are facing serious challenges in the global marketplace. The newly emerging countries and other highly developing ones are poised to capture an ever increasing significant share of the global markets and this with the respective government policies that support their education systems, particularly in the sciences, that provide funding to their corporate $\mathrm{R} \& \mathrm{D}$ and that give subsidies to their respective trades and strategic industries. Similarly, for the U.S. corporations to remain competitive in the global marketplace, the U.S. government must continue providing the much needed funding in the sciences and $R \& D$ programs. It must overhaul the education system, particularly the primary and secondary systems to bring them once again to the world standards, particularly in the areas of mathematics and physical sciences. A highly skilled labor workforce is the major force behind innovation in technology and increases in productivity. The U.S. government and corporations must provide scholarships and other incentives to attract the brightest students to study the disciplines critical to compete in the global economy. Cooperation between government and the private sector can lead to more students choosing to study engineering, mathematics and the sciences. Until recently the U.S. was able through an agressive recruitment process to fill a part of this void in sciences-related skilled workforce with the help of a highly and valuable foreign skilled workforce. Given the global competition for highly skilled workers and the events following 9-11, the retention of this foreign skilled workforce has been reduced and threatened. The U.S. government and corporations must address this immediate issue as well as the issues surrounding the overhauling of the educational system to world-class status. A world class primary and secondary education system, similar to the world class university system in the United States, would prepare and provide the talent to enter colleges and universities and study those disciplines necessary for the United States to remain competitive in the global economy. Finally, increases in R \& D funding by both government and the private sector are necessary to foster innovation and retain a position of global economic leadership.

\section{AUTHOR INFORMATION}

Anthony Narsing, PhD is an Associate Professor of Management at Macon State College. His research interests include: supply chain management, lean, RFID, quality and operations research.

Arav Ouandlous, $\mathrm{PhD}$ is a Professor of Economics and Finance at Savannah State University. His research interests include: Globalization, capital markets and international finance.

Harry McAlum, DBA is a Professor of Accounting at Macon State College. His research interests include: financial accounting, auditing and pedagogical research.

\section{REFERENCES}

1. AAAS, "American Association for Advancement of Science," American Physical Society of Public affairs, 2005.

2. Colvin, G., “America Isn’t Ready,” Fortune, July 25, 2005.

3. Dagnett, W and Pedinotti, J., "Globalization - Tipping the Scale of Economic Recovery," International Center for Leadership in Education, 2005.

4. $\quad$ Durbin, D., "Toyota Overtakes Ford as U.S. $2^{\text {nd }}$ Biggest," AP Auto Writer, Jan 2008.

5. $\quad$ Engardio, P., "A New Word Economy,” Business Week, August 22/29, 2005.

6. $\quad$ Fishman, T., "China, Inc", Scribner: New York, 2005.

7. Freedman, T., "The World is Flat," Farrar, Strauss and Giroux: New York, 2005.

8. Mahapatra, R., "Microsoft to Invest in India, Add Jobs," Associated Press, December 2005.

9. NSFEI, "National Science Foundation and Engineering Indicators," 2006.

10. Offshore IT Outsourcing, "Benefits of IT Outsourcing to India- Economy", http://offshoreitoutsourcing.com/Pages/India_Economy.asp, 2007.

11. PRNewswire, "Radilogy Outsourcing in India: IMC Breaks New Ground," http://www.redorbit.com/news/health/628239/radiology_outsourcing_in_india_imc_breaks_new_ground/in dex.html?source=r_health, 2006

12. Stevenson, J. Williams, “Operations Management", $9^{\text {th }}$ Edition, (2007), McGraw-Hill/ Irwin Publishing

13. Thornton, M., "The Japanese Bubble Economy," LewRockwell.com, 2007. 